\title{
The effect of exogenous leptin on pancreatic enzyme secretion in anaesthetized rats*
}

\author{
R. Matyjek ${ }^{1,4}$, J. Woliński ${ }^{1}$, D. Laubitz ${ }^{1}$, S. Kato ${ }^{2}$ and R. Zabielski ${ }^{1,3}$ \\ ${ }^{I}$ The Kielanowski Institute of Animal Physiology and Nutrition, Polish Academy of Sciences \\ 05-110 Jabłonna, Poland \\ ${ }^{2}$ Department of Veterinary Physiology, School of Veterinary Medicine \\ Rakuno Gakuen University Ebetsu \\ Hokkaido 069-8501, Japan \\ ${ }^{3}$ Department of Physiological Sciences, Faculty of Veterinary Medicine, \\ Warsaw Agricultural University \\ 02-766 Warsaw, Poland
}

(Received 22 December 2004; accepted 18 March 2005)

\begin{abstract}
The influence of leptin on the secretion of pancreatic juice was examined in biliary-pancreatic duct-cannulated anaesthetised rats. Exogenous leptin was given in boluses either intravenously or intraduodenally. A low dose of leptin $(0.1 \mu \mathrm{g} / \mathrm{kg} \mathrm{BW})$ had no effect on pancreatic secretion. Leptin in a dose of $1 \mu \mathrm{g} / \mathrm{kg}$ BW given intravenously inhibited protein and amylase output only when the exocrine pancreas was stimulated by CCK-8 (12 pmol/kg BW, iv). Leptin in a high, pharmacological dose (10 $\mu \mathrm{g} / \mathrm{kg} \mathrm{BW}$ ) given intravenously inhibited juice secretion, protein and amylase output, whereas given intraduodenally, stimulated them. Intravenous infusion of 2-deoxy-glucose $(0.25 \mathrm{~g} / \mathrm{kg} \mathrm{BW}$ per h) induced pancreatic juice secretion, which was abolished by a leptin bolus $(10 \mu \mathrm{g} / \mathrm{kg} \mathrm{BW})$. In conclusion, leptin can regulate the exocrine pancreas via different mechanisms.
\end{abstract}

KEY WORDS: leptin, pancreas, rat, pancreatic secretion

\section{INTRODUCTION}

Leptin is a 167 -amino acid protein, produced and secreted to the circulating blood by the adipose tissue and various other tissues including stomach mucosa

\footnotetext{
* Supported by JSPS, Japan (ID No. S-00268) and the State Committee for Scientific Research, Grant No. 3 P06K 00324

${ }^{4}$ Corresponding author: e-mail: r.matyjek@ifzz.pan.pl
} 
(Bado et al., 1998). The involvement of leptin in the central regulation of food intake and body weight homeostasis is being intensively investigated, whereas information on the role of leptin in the gastrointestinal tract is scanty, though abundant leptin receptors have been demonstrated in the stomach (Mix et al., 2000; Sobhani et al., 2000) and small intestine (Losato et al., 1998; Morton et al., 1998). In the pancreas the receptors are localised on the $\beta$-cells (Kieffer et al., 1996) and acinar cells (Harris et al., 1999; Jaworek et al., 2002) suggesting possible involvement of leptin in the regulation of its endocrine and exocrine function. Indeed, we have recently demonstrated that exogenous leptin inhibits pancreatic enzyme protein output in anaesthetized rats (Matyjek et al., 2003). The action of leptin was, however, not focussed on the regulation of pancreatic acinar cells directly, but on the inhibition of a neuro-hormonal mechanism involving CCK and vagal nerves, which is considered to be the main physiological mechanism controlling exocrine pancreas function (Deng and Whitcomb, 1998).

Food and exogenous CCK-8, both resulted in a rapid and large decrease in the leptin content of the fundic epithelium, with a concomitant increase in the concentration of leptin in the blood plasma as well as in the gastric lumen in rats (Brzozowski et al., 1999). Intravenous infusions of pentagastrin or secretin caused an immediate increase in circulating leptin levels and leptin release into the gastric juice in humans (Sobhani et al., 2000). The role of leptin released into the gastric lumen on the secretion of pancreatic juice remains unclear, though inhibition by luminal somatostatin (Konturek et al., 1981), and stimulation by luminal CCK-8 (Zabielski et al., 1998) have been demonstrated in whole animal studies.

The aim of the present study was to investigate the effect of exogenous leptin infused intravenously (iv) or intraduodenally (id) on the secretion of pancreatic juice in anaesthetized rats. The secretion of pancreatic juice is also controlled by an insulo-acinar axis involving insulin released from islet $\beta$-cells, and Seufert et al. (1999) have shown that leptin may interfere with insulin synthesis and release. This suggests that in addition to the inhibition of the above-mentioned neurohormonal CCK-vagal-dependent mechanism, circulating leptin may inhibit pancreatic enzyme secretion indirectly via modulation of insulin release. Thus the second part of the study aimed to clarify the role of leptin in this mechanism. Intravenous administration of 2-deoxy-glucose (2DG) was used to stimulate the release of endogenous insulin from the islets via a cholinergic pathway (Karlsson et al., 1987) and without a direct effect on pancreatic acini (Meyer et al., 1999). 


\section{MATERIAL AND METHODS}

\section{Animal model}

The animal studies were approved by the Local Ethics Committee. A total of 48 male rats weighing $297 \pm 9 \mathrm{~g}$ were used. The animals were housed in a lightand temperature-controlled room with free access to laboratory feed and water, and were deprived of feed during the night before the experiment. The rats were anaesthetized with ketamine (subcutaneous - sc, $50 \mathrm{mg} / \mathrm{kg} \mathrm{BW}$, Bioketan, Biowet, Gorzów, Poland). Body temperature was continuously controlled and maintained by heating lamps. The right external jugular vein was catheterized with silicone tubing, and continuous iv infusion of saline $(0.9 \% \mathrm{NaCl})$ by means of a peristaltic pump $(2 \mathrm{ml} / \mathrm{h})$ was started immediately. The infusion was continued until the end of the experiment. Following midline laparotomy, polyethylene tubing was inserted into the common pancreatico-billiary duct for collection of bile and pancreatic juice (PBJ), and in 6 rats an additional silicone catheter was installed in the proximal duodenum for intraduodenal infusion of leptin. Ketamine injections (sc, $30 \mathrm{mg} / \mathrm{kg} \mathrm{BW}$ ) were repeated once or twice to maintain the anaesthesia during the whole experiment. Collection of PBJ started immediately after completing the surgery and the experimental protocol started $30 \mathrm{~min}$ thereafter. PBJ was collected in $15 \mathrm{~min}$ intervals into $1.5 \mathrm{ml}$ polyethylene tubes kept in an ice-cold bath. Collected PBJ was not infused into the duodenum and was stored at $-20^{\circ} \mathrm{C}$ for further analyses. After the experiments all of the animals were killed by intravenous pentobarbiturate overdose.

\section{Effect of intravenous and intraduodenal administration of leptin}

Vehicle $(0.9 \% \mathrm{NaCl})$ and three leptin boluses $(0.1,1.0,10 \mu \mathrm{g} / \mathrm{kg} \mathrm{BW}$, Leptin mouse recombinant, Sigma, St. Louis, USA) were given either intravenously or intraduodenally every $30 \mathrm{~min}$. Three series of experiments were performed to test PBJ secretion following iv leptin infusion. In the first series $(n=6)$, the effect of leptin alone was studied. In the second series $(n=6)$, the effect of leptin doses during continuous intravenous infusion with a low dose of CCK-8 (12 pmol/kg BW per h, synthetic CCK-octapeptide sulphate, Peptide Institute Inc., Osaka, Japan) was studied. In the third series $(n=6)$, the effect of leptin doses during continuous iv infusion with a high dose of CCK-8 (120 pmol/kg BW per h) was studied. The effect of continuous intravenous infusion of CCK-8 (120 pmol/kg BW per $h)$ on PBJ secretion was examined in the fourth series $(n=6)$. In the fifth series, the effect of leptin alone administered into the duodenum lumen was studied $(n=6)$. 


\section{Effect of leptin on the insulo-acinar axis}

The study protocol $(\mathrm{n}=18)$ started with 30 min continuous intravenous infusion of $0.9 \% \mathrm{NaCl}$. After that, saline was replaced with 2-deoxy-glucose infusion $(0.25$ $\mathrm{g} / \mathrm{kg}$ BW per h, Sigma) to induce endogenous insulin release (Karlsson et al., 1987). In 12 rats, a single leptin bolus of $1 \mu \mathrm{g} / \mathrm{kg} \mathrm{BW}(\mathrm{n}=6)$ or $10 \mu \mathrm{g} / \mathrm{kg} \mathrm{BW}$ $(n=6)$ was given intravenously following $30 \mathrm{~min}$ of 2DG.

Analyses

The PBJ samples were analysed for total protein using the Lowry method, performed on 96-well microwell plates with bovine serum albumin (Sigma, USA) as the standard. Amylase activity was measured according to the Bernfelt method with maltose (Sigma) as the standard. The results were calculated as means and the standard error of mean (SEM) for 15-min collection intervals. The dose-response data of iv and id leptin boluses were expressed in relative values, taking the initial $15 \mathrm{~min}$ response to vehicle $(0.9 \% \mathrm{NaCl})$ as $100 \%$. One-way variance analysis for repeated measures followed by a Tukey posttest and a linear trend analysis was performed (GraphPad Prism v.3, Graph Pad Software, San Diego, CA, USA) to investigate the relationships between the dose of leptin and PBJ secretory response as well as to measure the differences between the control and leptin-treated rats in the 2DG study. A value of $\mathrm{P}<0.05$ was considered statistically significant.

\section{RESULTS}

Leptin does not affect bile flow (Nemecz et al., 1999), thus changes in PBJ flow concern the secretion of pancreatic juice. In anaesthetized rats, the iv infusion of saline did not affect the PBJ volume flow, protein and enzyme outputs. Continuous infusion of the low dose of CCK- 8 did not affect the PBJ volume and roughly doubled PBJ protein and amylase outputs. The large dose of CCK-8 increased PBJ volume flow by $25 \%$, protein output by about $300 \%$, and pancreatic amylase output by about $400 \%$ and maintained it on an elevated level until the end of PBJ collection (data not shown).

Effect of intravenous and intraduodenal administration of leptin. Intravenous infusion of leptin at a dose of $10 \mu \mathrm{g} / \mathrm{kg} \mathrm{BW}$ reduced the secretion of PBJ (Figure 1). Although continuous background infusions of low and high doses of CCK-8 markedly elevated the basal PBJ flow, they did not change the incremental 


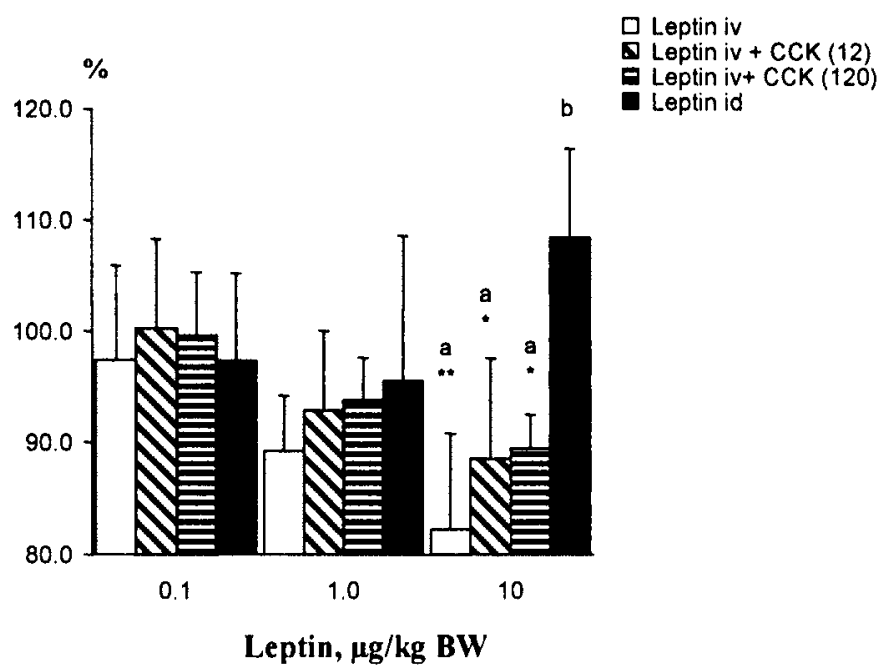

Figure 1. Effect of intravenous infusion of leptin on non-stimulated and CCK-8-stimulated PBJ volume secretion in anaesthetized rats. $100 \%$ indicates a response to vehicle infusion $(0.9 \% \mathrm{NaCl})$; values are given as a percentage of volume following vehicle infusion. Values are shown as means and their standard errors are indicated by vertical bars. For details on the number of animals and on the calculations, see Materials and Methods. *Mean value was significantly different from the respective vehicle infusion (one-way ANOVA for repeated measurements followed by the Tukey test, ${ }^{*} \mathrm{P}<0.05$, $* * \mathrm{P}<0.01)$. Different small letters over the bars indicate a statistical difference between the mean values within a given leptin dose (one-way ANOVA followed by the Tukey test)

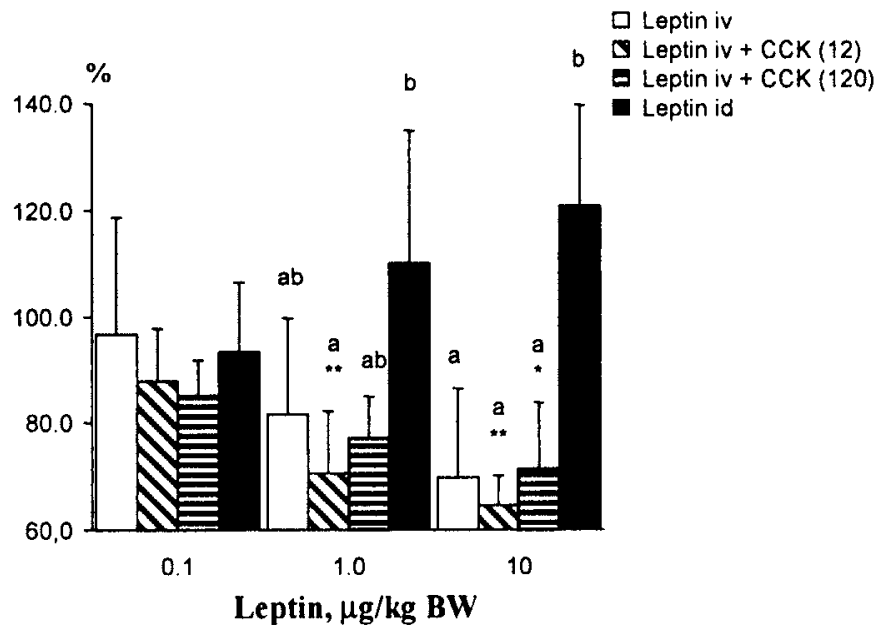

Figure 2. Effect of intravenous infusion of leptin on non-stimulated and CCK-8-stimulated PBJ protein output in anaesthetized rats. For details see text and Figure 1 


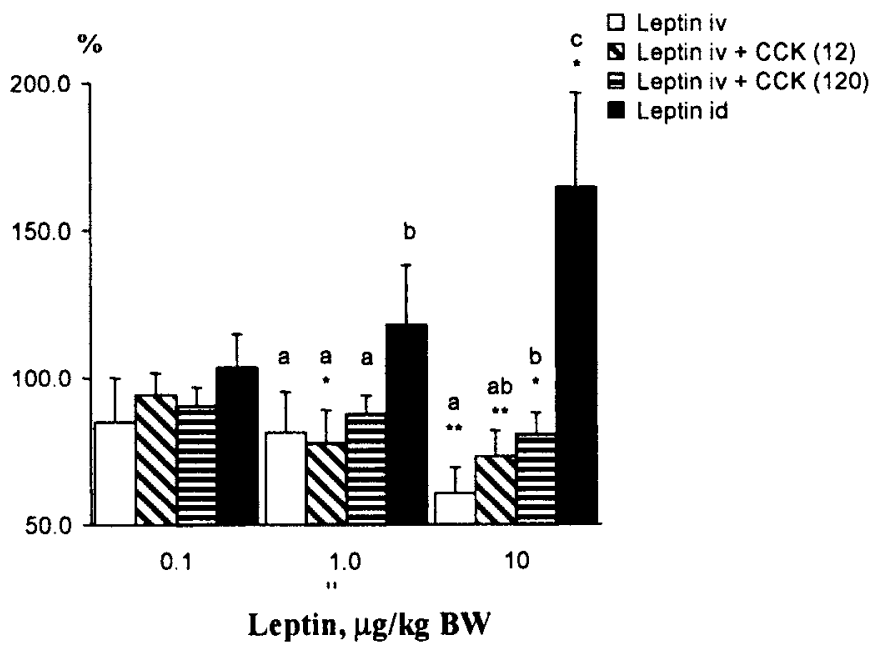

Figure 3. Effect of intravenous infusion of leptin on non-stimulated and CCK-8-stimulated pancreatic amylase output in anaesthetized rats. For details see text and Figure 1

volume response to exogenous leptin. Administration of exogenous leptin decreased the protein output (Figure 2) and amylase activity (Figure 3) in PBJ in a dose-related manner (test for linear trend $\mathrm{P}>0.001$ ). Following the infusion of leptin alone, the inhibition was statistically significant only for the highest dose. However, under conditions of stimulation by a low dose of CCK-8, the two doses of leptin ( 1 and $10 \mu \mathrm{g} / \mathrm{kg} \mathrm{BW}$ ) produced significant inhibition of protein and amylase output. When considering the absolute values, the administration of these two doses of leptin abolished the stimulation of PBJ caused by the low dose of CCK-8.

Although a tendency towards an increase could be observed, intraduodenal administration of increasing doses of leptin had no significant effect on the volume of pancreatic juice and protein output as compared with the intraduodenal infusion of vehicle (Figures 1 and 2). In respect to amylase output, however, the highest dose of leptin caused significant stimulation as compared with the respective vehicle infusion (Figure 3). Moreover, intraduodenal infusions of the two doses of leptin (1 and $10 \mu \mathrm{g} / \mathrm{kg} \mathrm{BW}$ ) caused significantly higher pancreatic responses than the same doses given intravenously (Figures 1-3).

Effect of leptin on the insulo-acinar axis. Intravenous infusion of 2DG did not change the volume of PBJ (Figure 4), but significantly increased $(\mathrm{P}<0.05)$ PBJ protein output (Figure 5). Intravenous leptin boluses did not significantly affect the PBJ volume but did abolish the elevation in protein output produced by 2DG infusion, in a dose-related manner (Figure 5). 


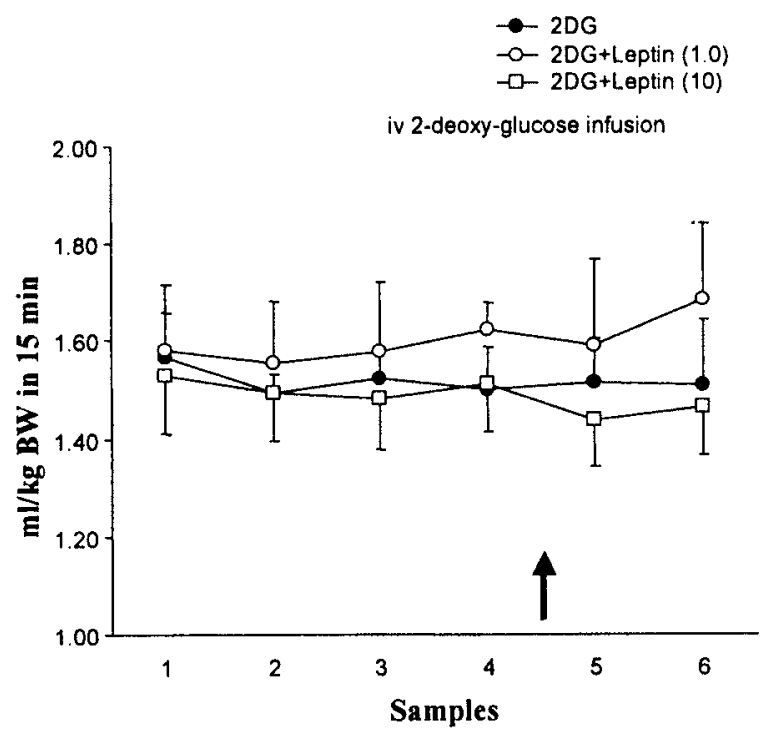

Figure 4. Effect of intravenous bolus infusion of 1 and $10 \mu \mathrm{g} / \mathrm{kg} \mathrm{BW}$ leptin (arrow) on PBJ volume in 2-deoxy-glucose (2DG) intravenously perfused anaesthetized rats. Values are shown as means, standard errors are indicated by vertical bars. For details see Material and methods

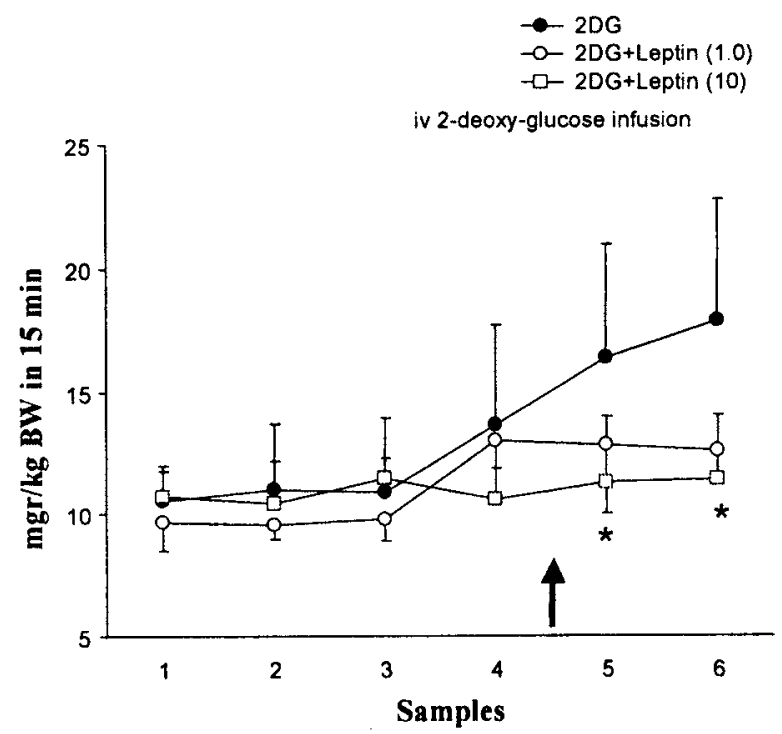

Figure 5. Effect of intravenous bolus infusion of control, leptin (arrow) groups (1 and $10 \mu \mathrm{g} / \mathrm{kg} \mathrm{BW}$ ) on PBJ protein output in 2-deoxy-glucose (2DG) intravenously perfused anaesthetized rats. Values are shown as means and their standard errors are indicated by vertical bars. For details on the number of animals and on the calculations, see Material and methods. Asterisks show a statistical difference between the three series of experiments in the given time points (analysis of variance followed by Tukey test) 


\section{DISCUSSION}

The present study confirms that circulating leptin may inhibit the secretion of pancreatic juice (Matyjek et al., 2003) and shows that gut luminal leptin has an effect opposite to that of circulating leptin in anaesthetized rats. Although leptin receptor mRNA was demonstrated on AR42J (Harris et al., 1999) and normal (Jaworek et al., 2002) pancreatic acinar cells, our functional studies with pancreatic acinar cells in vitro could not confirm the role of the leptin receptor in controlling pancreatic amylase secretion (Matyjek et al., 2003). Instead, the present results suggest that circulating leptin may act on the exocrine pancreas by inhibiting the insulo-acinar axis in the anaesthetized rat.

We found that in in vivo conditions, both non-stimulated and CCK-8-stimulated pancreatic secretion is reduced by infusion of leptin, however, the stimulation with a high dose of CCK- 8 and lack of CCK-8 stimulation caused an apparently weaker inhibitory response to leptin than stimulation with a low dose of CCK-8 (12 pmol/ $\mathrm{kg} \mathrm{BW})$. Recently, we observed no effect of leptin on pancreatic protein output following deactivation of sensory nerves with capsaicin and vagotomy (Matyjek et al., 2003). According to Li and Owyang $(1993,1996)$, in the anaesthetized rat low doses of CCK control the exocrine pancreas via a duodenal mechanism that depend on vagal afferents rather than by direct stimulation of $\mathrm{CCK}_{1}$ receptors located on pancreatic acini. The latter (direct) mechanism is turned on only after administration of pharmacological doses of CCK. In our study, high doses of leptin reversed the secretion stimulated by a low dose of CCK- 8 but not by the high dose of CCK-8.

We did not measure either CCK or leptin concentrations in the circulating blood in the examined rats, thus we can-not discuss eventual endogenous CCK release following leptin administration and vice versa as shown previously (Brzozowski et al., 1999, Guilmeau et al., 2002), however, the present results of intraduodenal infusion of leptin on protein output and amylase release were opposite to the result of intravenous administration (Figures 2 and 3). Using a rat model similar to ours, Guilmeau et al. (2002) observed stimulation of pancreatic juice secretion following intravenous leptin. The doses of leptin were, however, 16 to 160 times higher than in the present study. Possibly, large doses of intravenous leptin (Guilmeau et al., 2002) could increase the leptin concentration in the gastrointestinal mucosa high enough to induce the mechanism dependent on the duodenal infusion of leptin in our study. Recent data obtained by Guilmeau et al. (2003) strongly support this hypothesis. They have found that rat duodenal juice contains leptin, and that duodenal infusion of leptin increases plasma CCK at levels comparable to those induced by feeding. These results were further confirmed in vitro by demonstrating that leptin can 
induce CCK release from the CCK-producing STC-1 cells (Guilmeau et al., 2003). Taken the data together it seems that at the duodenal mucosa level leptin and CCK may potentiate their own effects.

In rat and human nodose ganglia, vagal afferent neurones co-express the $\mathrm{CCK}_{1}$ receptor and OB-Rb leptin receptor providing a neurochemical basis for observations of interactions between CCK and leptin (Burdyga et al., 2002). Wang et al. (1997) demonstrated two types of leptin-responsive gastric vagal afferent terminals: type 2 that requires interaction with CCK, and type 1, which acts independently. They speculated that type 2 units generate acute satiety-related afferent signals to the central nervous system, while type 1 units may act as sensors to monitor concentration changes of leptin. These findings were recently confirmed in vivo by Gaige et al. (2002) who demonstrated stimulatory, inhibitory, and leptin-insensitive units. In addition, timing of the injections of CCK and leptin resulted in different responses. The effect of the activation of these different afferent units on gastric or pancreatic secretion has not been elucidated. Also the presence of leptin-responsive vagal afferent terminals in the duodenum has not been reported to our knowledge. Moreover, leptin was shown to increase the local blood flow through CGRP release and increased generation of NO (Brzozowski et al., 2001; Jaworek et al., 2002; Warzecha et al., 2002).

In the perfused rat pancreas preparations, leptin failed to alter the insulin secretion elicited by glucose, arginine or tolbutamide, but inhibited the insulin response to carbachol (Silvestre et al., 2001). In whole animal studies, 2DG is used to induce the release of endogenous insulin via a vagal cholinergic pathway (Karlsson et al., 1987), which in turn intensifies the secretion of pancreatic juice in anaesthetised rats (Iwabe et al., 2001). Carlson et al. (1999) showed that vagal mechanisms indeed play a crucial role in insulin release but are also responsible for controlling pancreatic islet blood flow. On the other hand, leptin has been implicated in causing peripheral insulin resistance by attenuating insulin action in insulin-responsive cells (Houseknecht et al., 1998). Nevertheless, in the present study circulating leptin was found to abolish the secretion of pancreatic juice that was stimulated by the activation of the insulo-acinar axis, though the precise mechanism can not be deduced from the in vivo research.

In conclusion, we have demonstrated that exogenous leptin, depending on the route of administration, may have opposite effects on the secretion of pancreatic juice in anaesthetised rats. More studies are necessary, however, to clarify the involvement of particular mechanisms, and their physiological relevance. 


\section{REFERENCES}

Bado A., Levasseur S., Attoub S., Kermorgant S., Laigneau J.P., Bortoluzzi M.N., Moizo L., Lehy T., Guerre-Millo M., Le Marchand-Brustel Y., Lewin M.J., 1998. The stomach is a source of leptin. Nature 394, 790-793

Brzozowski T., Konturek P.C., Konturek S.J., Pajdo R., Duda A., Pierzchalski P., Bielański W., Hahn E.G., 1999. Leptin in gastroprotection induced by cholecystokinin or by a meal. Role of vagal and sensory nerves and nitric oxide. Eur. J. Pharmacol. 374, 263-276

Brzozowski T., Konturek P.C., Pajdo R., Kwiecień S., Ptak A., Sliwowski Z., Drozdowicz D., Pawlik M., Konturek S.J., Hahn E.G., 2001. Brain-gut axis in gastroprotection by leptin and cholecystokinin against ischemia-reperfusion induced gastric lesions. J. Physiol. Pharmacol. 52, 583-602

Burdyga G., Spiller D., Morris R., Lal S., Thompson D.G., Saeed S., Dimaline R., Varro A., Dockray G.J., 2002. Expression of the leptin receptor in rat and human nodose ganglion neurones. Neuroscience 109, 339-347

Carlsson P.O., Iwase M., Jansson L., 1999. Stimulation of intestinal glucoreceptors in rats increases pancreatic islet blood flow through vagal mechanisms. Amer. J. Physiol. 276, R233-R236

Deng X., Whitcomb D.C., 1998. Neurohormonal control of the exocrine pancreas. Curr. Opin. Gastroenterol. 14, 362-368

Gaige S., Abysique A., Bouvier M., 2002. Effects of leptin on cat intestinal vagal mechanoreceptors. J. Physiol. 543, 679-689

Guilmeau S., Buyse M., Tsocas A., Laigneau J.P., Bado A., 2003. Duodenal leptin stimulates cholecystokinin secretion: evidence of a positive leptin-cholecystokinin feedback loop. Diabetes 52,1664-1672

Guilmeau S., Nagain-Domaine C., Buysse M., Tsocas A., Roze C., Bado A., 2002. Modulation of exocrine pancreatic secretion by leptin through CCK1-receptors and afferent vagal fibres in the rat. Eur. J. Pharmacol. 447, 99-107

Harris D.M., Flannigan K.L., Go V.L., Wu S.V., 1999. Regulation of cholecystokinin-mediated amylase secretion by leptin in rat pancreatic acinar tumor cell line AR42J. Pancreas 19, 224-230

Houseknecht K.L., Baile C.A., Matteri R.L., Spurlock M.E., 1998. The biology of leptin: A review. J. Anim. Sci. 76, 1405-1420

Iwabe C., Shiratori K., Shimizu K., Hayashi N., 2001. Role of endogenous insulin in pancreatic secretion in rats. Pancreatology 1, 300-305

Jaworek J., Bonior J., Leja-Szpak A., Nawrot K., Kot M., Tomaszewszka R., Stachura J., Pawlik W.W., Konturek S.J., 2002. Sensory nerves in central and peripheral control of pancreatic integrity by leptin and melatonin. J. Physiol. Pharmacol. 53, 51-74

Karlsson S., Bood M., Ahren B., 1987. The mechanism of 2-deoxy-glucose-induced insulin secretion in the mouse. J. Auton. Pharmacol. 7, 135-44

Kieffer T.J., Heller R.S., Habener J.F., 1996. Leptin receptors expressed on pancreatic beta-cells. Biochem. Biophys. Res. Commun. 224, 522-527

Konturek S.J., Tasler J., Cieszkowski M., Jaworek J., Arimura A., Schally A.V., 1981. Studies on the inhibition of pancreatic secretion by luminal somatostatin. Amer. J. Physiol. 241, G109-G115

Li Y., Owyang C., 1993. Vagal afferent pathway mediates physiological action of cholecystokinin on pancreatic enzyme secretion. J. Clin. Invest. 92, 418-424

Li Y., Owyang C., 1996. Pancreatic secretion evoked by cholecystokinin and non-cholecystokinindependent duodenal stimuli via vagal afferent fibres in the rat. J. Physiol. 494, 773-782

Lostao M.P., Urdaneta E., Martinez-Anso E., Barber A., Martinez J.A., 1998. Presence of leptin receptors in rat small intestine and leptin effect on sugar absorption. FEBS Lett. 423, 302-306 
Matyjek R., Herzig K.-H., Kato S., Zabielski R., 2003. Exogenous leptin inhibits the secretion of pancreatic juice via a duodenal CCK1-vagal-dependent mechanism in anaesthetized rats. Regul. Peptides 114, 15-20

Meyer V., Kadiata M.M., Malaisse W.J., 1999. Stimulation by 2-deoxy-D-glucose tetraacetates of hormonal secretion from the perfused rat pancreas. Amer. J. Physiol. 276, E689-E696

Mix H., Widjaja A., Jandl O., Cornberg M., Kaul A., Goke M., Beil W., Kuske M., Brabant G., Manns M.P., Wagner S., 2000. Expression of leptin and leptin receptor isoforms in the human stomach. Gut 47, 481-486

Morton N.M., Emilsson V., Liu Y.L., Cawthorne M.A., 1998. Leptin action in intestinal cells. J. Biol. Chem. 273, 26194-26201

Nemecz M., Preininger K., Englisch R., Furnsinn C., Schneider B., Waldhausl W., Roden M., 1999. Acute effect of leptin on hepatic glycogenolysis and gluconeogenesis in perfused rat liver. Hepatology 29, 166-172

Seufert J., Kieffer T.J., Habener J.F., 1999. Leptin inhibits insulin gene transcription and reverses hyperinsulinemia in leptin-deficient ob/ob mice. Proc. Natl. Acad. Sci. USA 96, 674-679

Silvestre R.A., Rodriguez-Gallardo J., Egido E.M., Marco J., 2001. Effect of leptin on insulin glugacon and somatostatin secretion in the perfused rat pancreas. Horm. Metab. Res. 33, 207-12

Sobhani I., Bado A., Vissuzaine C., Buyse M., Kermorgant S., Laigneau J.P., Attoub S., Lehy T., Henin D., Mignon M., Lewin M.J., 2000. Leptin secretion and leptin receptor in the human stomach. Gut 47, 178-183

Wang Y.H., Tache Y., Sheibel A.B., Go V.L., Wie J.Y., 1997. Two types of leptin-responsive gastric vagal afferent terminals: an in vitro single-unit study in rats. Amer. J. Physiol. 273, R833-R837

Warzecha Z., Dembinski A., Ceranowicz P., Jaworek J., Konturek P.C., Dembinski M., Bilski J., Konturek S.J., 2002. Influence of leptin administration on the course of acute ischemic pancreatitis. J. Physiol. Pharmacol. 53, 775-90

Zabielski R., Leśniewska V., Borlak J., Gregory P.C., Kiela P., Pierzynowski S.G., Barej W., 1998. Effects of intraduodenal administration of tarazepide on pancreatic secretion and duodenal EMG in neonatal calves. Regul. Peptides 78, 113-123

\section{STRESZCZENIE}

\section{Wpływ egzogennej leptyny na sekrecję enzymów trzustkowych u szczurów pod narkozą}

Wpływ egzogennej leptyny na sekrecję soku trzustkowego u szczurów badany był przy użyciu ostrego modelu doświadczalnego kolekcji soku trzustkowego i żółci pod narkozą. Zwierzętom implantowano kateter szyjny oraz kateter do przewodu żółciowo-trzustkowego wspólnego. Sok zbierano co 15 minut i zamrażano do oznaczenia białka ogólnego i amylazy. Sok w tym modelu nie był zwracany do dwunastnicy. Leptyna podawana była w bolusie dożylnie lub do dwunastnicy w trzech dawkach co pół godziny. Leptyna podana zarówno dożylnie jak i do dwunastnicy w najniższej dawce $(0,1 \mu \mathrm{g} / \mathrm{kg})$ nie miała wpływu na sekrecję soku trzustkowego. Średnia dawka fizjologiczna $(1 \mu \mathrm{g} / \mathrm{kg})$ istotnie zahamowała wydzielanie białka i amylazy w soku tylko w obecności CCK-8 podawanej w dożylnie w ilości $12 \mathrm{pmol} / \mathrm{kg} / \mathrm{godz}$. Dawka $10 \mu \mathrm{g} / \mathrm{kg}$, podana dożylnie zahamowała sekrecję soku oraz amylazy. Podanie leptyny do dwunastnicy w ilości 1 i $10 \mu \mathrm{g} / \mathrm{kg}$ wywołało istotną stymulację wydzielania. Reasumując leptyna może wpływać na wydzielanie soku trzustkowego poprzez działanie na różne mechanizmy regulacji. 